ПРИРОДНИЧІ НАУКИ. ТЕХНОЛОГІЇ

УДК 378.6+76.021

DOI: 10.37026/2520-6427-2020-103-3-140-143
Любов ІЛЬНИЦЬКА,

кандидат філософських наук,

доиент кафедри дизайну

Українського гуманітарного інституту, м. Київ

\title{
НАУКОВО-МЕТОДИЧНІ РЕКОМЕНДАЦЇ̈ ЩОДО ВИКОНАННЯ ТВОРЧОГО ЗАВДАННЯ «ТЕМАТИЧНИЙ ЕКСЛІБРИС»
}

Призначення представлених науково-методичних рекомендаиій полягає у дочільності засадничих підходів до виконання творчого завдання «тематичний екслібрис». Сформовані авторські інструкиійні методичні рівні були використані при заздалегідь передбаченій участі студентів першого року навчання зі спеціальності 5.02020701 "Дизайн» у виставиі студентських робіт, щео мала назву «Новорічний екслібрис» (2019/2020 рр.).

Ключові слова: книжковий екслібрис, експозиційний проєкт, художня творчість, «художнє зосередження», науково-методичні рекомендації.

Значение представленных научно-методических рекомендаций основывается на иелесообразности основных подходов к реализации творческого задания «тематический экслибрис». Сформированные авторские инструкиионные методические уровни были использованы при предварительно согласованном участии студентов первого года обучения по спеиииальности «Дизайн» в выставке студенческих работ «Новогодний экслибрис» (2019/2020 г2.).

Ключевые слова: книжный экслибрис, экспозиционный проект, художественное творчество, «художественная сосредоточенность», научно-методические рекомендации.

The purpose of the presented scientific and methodological recommendations is to reveal the main approaches to the execution of the creative assignment "thematic bookplate». The generated author's instruction with certain methodological levels of the bookplate was used in preparation for the participation in the exhibition of student works, which was called "New Year's bookplate».

This article points out essential creative details, that must be taken into account, since with the constant planning of compositional options for student work, due attention should be paid separately to text and font support, because, in this case, the main artistic and historical condition, due to which the book ex-libris stands out is as a special sign, it is the obviousness of the corresponding inscription in Latin letters in the picture "EX LIBRIS». These words reveal the purpose of this graphic work - to display a kind of entry into the historical world of book culture.
The presented methodological development is complemented by scientific commentaries and clear support of the appropriate level of argumentation of the name of the path that allows this study to reveal the possibilities of training students, including through the author's conceptual explication of such an important aesthetic and educational means as «artistic concentration». Therefore, in preparation for the exhibition and exposition activities, it is necessary to identify the possibilities of the creative potential of talented youth within the framework of the specifics of the task additional to the main program to create your own book sign in the thematic style of the «New Year's ex-libris».

Key words: book ex-libris, exposition project, artistic creation, "artistic concentration», scientific and methodological recommendations.

Постановка завдання. Розробка науково-методичних рекомендацій $\epsilon$ необхідною частиною загальної навчально-виховної роботи, яка додатково передбачає й індивідуальну підготовку студентів мистецького напряму фахового спрямування «Дизайн» до участі у творчих проєктах. Практична цінність даного дослідження передбачена підготовкою до перевірки означеної розробки у межах чіткого терміну виконання та подання студентських робіт на академічний виставковий захід - «Новорічний екслібрис» (2019/2020 pp.).

Аналіз наукових досліджень та публікацій. У ракурсі запропонованих методичних рекомендацій площина наведеного завдання розкривається у двох взаємопов'язаних групах наукових джерел: у художньо-професійних методичних вказівках, авторами яких є Іван Кириченко, Володимир Черватюк [3; 6] та колектив авторів методичного посібника «Художня графіка» для студентів закладів вищої освіти за напрямом підготовки «Мистецтво» [4]. Також слід звернути увагу і на супутню мистецьку літературу унікального призначення [1; 5], де по-особливому каталогізовано представлений важливий художній зміст книжкового екслібриса.

Унікальність додаткових творчих завдань для студентів спеціалізованої мистецької підготовки у закладах вищої освіти полягає у відкритті неабиякого прагнення до «художнього зосередження» 
над поставленою метою - самобутньо осягнути зміст тематичного напряму в межах тих технічних прийомів, навички використання яких були здобуті студентами протягом семестру.

Виклад основного матеріалу. Цьогоріч на базі кафедри графічних мистецтв Національної Академії образотворчого мистецтва та архітектури (далі - HAOMA) проходила виставка-конкурс студентських робіт «Новорічний екслібрис». Експозиційний проєкт передбачав виконання різнопланових графічних робіт за встановленою тематикою - самостійно віднайти здобувачами освіти образно-лаконічну подачу новорічно-святкового змісту за принципами композиційної побудови книжкового екслібрису. Представлена науково-методична розробка має стати необхідним керівництвом 3 упровадження в освітній процес завдань, пов'язаних не тільки із традиційними жанрово-академічними постановками, а й із творчими винаходами фахового контексту. Зі свого боку цей підхід налаштовує креативний світ юнацької аудиторії на індивідуальне відтворення спеціалізованої теми особливими прийомами книжкової графіки. Також у дослідженні сфокусовано подається «практичний наратив» розкриття креативних здібностей студентів, які отримують бакалаврський рівень вищої освіти.

Наукові нововведення до організації методичної роботи полягають у тому, щоб розробити актуалізовану платформу педагогічних дій зі встановленими етапами поступового практичного виконання на підставі параметрів конкретизованого ситуативного завдання. Специфікою опрацювання педагогічного досвіду викладання мистецьких дисциплін зі зверненням до виставкової діяльності дозволяє у формі методичних вказівок та рекомендацій прокласти правильний шлях до швидкого наближення та чіткого рішення, аби уникнути зайвої вірогідності при реалізації запланованої мети - вдалого педагогічного результату при успішному розкритті творчих умінь студентської аудиторії.

На сьогодні потреба у підготовці запропонованого методичного матеріалу полягає в тому, щоб якісно закріпити та поглибити теоретичні знання, здобуті студентами у процесі фахового навчання й опанування дисциплін, дотичних до затвердженого кола предметів I-го семестру I-го бакалаврського рівня вищої освіти за напрямом підготовки «дизайн». Стратегічною метою цього завдання $є$ можливість перевірити ступінь оволодіння студентами певного рівня самостійного опрацювання і застосування первинного професійного інструментарію та розкрити спроможність використовувати студентами технологічні прийоми базових креативно-дизайнерських принципів роботи під час входження у тематичний напрям усвідомленого та зосередженого відтворення власного творчого задуму графічними засобами художньо-естетичної виразності. На думку заслуженого художника України Івана Кириченка, автора методичних рекомендацій щодо педагогічної технології входження у техніку глибокого друку, «завдання, що виконуються, засвоєний програмний матеріал мають забезпечувати втілення творчих робіт в офорті, що використовуватимуться у розробці реального проекту» [3, с. 111].

Складність підготовки до виставкової події полягає у безпосередній самостійній роботі студентів над виконанням конкурсних вимог більш вищого рівня, ніж загальнонавчальні. Це означає, що методична робота має вийти за межі усталених стандартів, але відповідати планові розвитку найвищих мистецьких традицій вищої освіти. Наприклад, Володимир Черватюк, автор розробки методичних рекомендацій із пленерного живопису, стверджує: «Зважаючи на базовепідгрунтя тієї освіти, яка була закладена в Українській академії мистецтва ще у 20-і роки минулого століття, утворилася певна система формування мислення творчої молоді $з$ новими мистецькими пошуками, що втілюються у цікаві художні твори і гідно представлені як у НАОМА, так і на різноманітних мистецьких виставках» [5, с. 44]. Підготовка студентів до участі у мистецькому виставковому проєкті «Нооворічний екслібрис» виявляє певні систематизовані етапи, які взаємопов'язані між собою і $є$ методично зафіксованими у сприятливих структурних положеннях із передбаченим дотриманням фахового призначення до цілеспрямованого виконання поставлених загальних вимог.

Структурно представлена методична розробка складається із кількох характерних для творчої роботи етапів:

1) ознайомлення із загальними та технічними вимогами;

2) перелік завдань до поступового виконання загальної мети;

3) ознайомлення із особливостями виконання творчих завдань;

4) інструкція до виконання творчого завдання «Новорічний екслібрис»;

5) практичні кроки щодо реалізації творчого ходу роботи.

Схарактеризуємо кожен із них докладніше.

\section{Загальні вимоги}

Отже, згідно із затвердженими положеннями про проведення студентської виставки «Новорічний екслібрис» студентські роботи повинні виконуватися на окремих аркушах паперу формату А 4. Техніка виконання цього завдання обумовлена стилістичною своєрідністю та тією художньою традицією, яку успадкував сучасний український екслібрис. Тому при опануванні певних жанрових особливостей книжкової графіки слід оглянути зразки, які представлені у наочному матеріалі $[1 ; 5]$.

Для студентів першого року навчання рекомендується використовувати у ході роботи над цим завданням (на ескізному етапі) матеріали, що є дотичними до цілого ряду графічних технік, як-от: маркери, олівці різного типу, акварельні фарби, проте для остаточного варіанту екслібрисного завдання (на завершальній стадії) найоптимальніше використовувати туш, чорнило, перо. Відповідно при обранні сприятливого графічно-зображувального засобу варто враховувати, що «палітра графічних технік сьогодні має величезний діапазон, що розширює можливості технічних та художніх прийомів зображення» [4, с. 71$]$.

\section{Перелік завдань}

- ознайомитися з характерною українською традицією графічного виконання тематичного екслібриса;

- схарактеризувати стилістичну специфіку саме «новорічного екслібриса»;

- сформувати ідею виконання творчого завдання;

- обрати техніку зображення;

- провести ескізний етап роботи;

- деталізовано опрацювати творчий задум;

- розкрити вміння поступового поєднання художнього образу зображення із текстовим супроводом.

- використати шрифти як ключовий супровід при загальному оформленні екслібрисного малюнка;

- заключний етап роботи, на якому затверджується остаточний варіант підготовки твору до оформлення. 
Оскільки завдання виконуються у додатковий час, тобто не передбачений затвердженим навчальним планом, етапи підготовки студентів першого року навчання до фінального виставкового етапу мають проходити на рівні погодження послідовного ескізного опрацювання самостійно обраної сюжетності та затвердження обраного варіанта виконання «Тематичного екслібрису» за напрямом «Новорічний мотив» у межах консультативної форми роботи, коли студентам у формі інформаційно-дорадчої співбесіди роз'яснюється поступовий хід проведення самостійної творчої роботи.

\section{Особливості виконання творчої роботи}

Задля висвітлення порядку виконання поставленого завдання попередньо має проводитися методично-роз'яснювальна робота у вигляді дидактико-інформативної вступної бесіди.

Перевага надається розкриттю специфіки екслібрису як особливого книжкового знаку із наочною демонстрацією видатних зразків цього напряму художньої думки. Крім того, під час консультацій аналізуються важливі для відображення святкові елементи й атрибути урочистої зустрічі Нового року та Різдва. Ці пропедевтичні, настановні дії покликані забезпечити необхідну глибину винайдення креативної винахідливості заради того, аби дати змогу студентам увійти у потрібний стан «художньої зосередженості». Зважаючи на власний педагогічний досвід роботи із творчою молоддю та спостерігаючи за тими помилками, які створюють перешкоди при виконанні певних художніх завдань, переконана, що в методичних розробках потрібно враховувати елементи ознайомлення 3 предметним світом унікального мистецького явища (у нашому випадку - екслібриса), що і сприятиме інформаційному входженню у простір представленої жанрової та тематичної специфіки. Окреслений перелік сполучних ланок має конкретизуватися у формі проведення консультативної бесіди 3 демонстрацією мистецьких зразків.

Отже, слід зробити окремий наголос на тому, що при висвітленні формування авторського стилю опрацювання важливих площинних акцентів саме екслібрисного малюнка передусім звертається увага на творчий доробок провідних українських майстрів малих форм графіки, до яких і відноситься екслібрис. Так, особливий внесок Олени Львівни Кульчицької, Петра Володимировича Нестеренка та Василя Євдокимовича Перевальського повною мірою відображає художньо-естетичну складову видовищного значення тих елементів екслібрисного малюнка, які становлять основу лінійної виразності довершеної стилістики графічного зображення книжкового знака.

Надалі, після деталізованого порівняння найвищих зразків художньої графіки [1] попередньої зазначеної специфіки, слід наголосити на пріоритетних етапах роботи, сфокусувати увагу на проведенні підготовчого етапу з відібраним переліком необхідних стратегічних підходів для виконання етюдних варіантів індивідуально затвердженого плану.

Заздалегідь обравши матеріали для виконання творчої роботи, варто плавно переходити до послідовного відтворення творчого завдання 3 використанням обраної техніки, яка може бути і змішаною, наприклад, ефективним буде застосовування етюдно-акварельних прийомів зображення із залученням малюнка графітними або вугільними олівцями.

\section{Інструкція до виконання творчого завдання "Новорічний екслібрис»}

Тема завдання: підготовка та відбір студентських робіт до участі в тематичній виставці.

Для того, щоб зрозуміти, як відбувається професійне становлення та розкриття творчих навичок студентів-дизайнерів, слід поступово залучати молодь до участі у виставковій діяльності через входження у додатковий вимір пізнання складних прийомів графічного зображення особливого книжкового знаку екслібриса. Існує своєрідна класифікація екслібриса за тематичним наповненням. Безперечно, тривала історія виникнення цієї поширеної європейської художньої форми візуалізації індивідуальної авторської інформації виокремлюється завдяки стилістично-самобутньому, видовищно-графічному способу відтворення унікального образного узагальнення. Разом із тим, «екслібрисна своєрідність» пов'язується з актуальним символічним естетичним змістом - підносити просвітницький сенс книжкової справи та звеличувати плеяду корифеїв літературної царини творчого буття.

Як зазначає П. В. Нестеренко, «екслібрис - це самодостатній мистецький твір, здатний рівнозначно 3 іншими жанрами графіки реагувати на запити й реалії життя, на інтелектуальну специфіку часу» [5, с. 3]. Розкрити практичний зміст наведеного визначення можливо тільки завдяки ментальним процесам «художнього зосередження». Таким чином, ретельне вивчення специфіки «екслібрисного гатунку» дає можливість правильного образного схоплення 3 подальшим детальним опрацюванням потрібного сюжету і своєчасного переходу до обрання тих художніх засобів, що відповідають поставленому завданню.

Слід урахувати, що матеріально-технічне забезпечення для виконання представленого завдання екслібрисного рішення зимово-святкового сюжету складається із такого переліку:

- туш та пера різних розмірів;

- декілька аркушів паперу для графічних робіт формату А 4 різного ступеня щільності;

- пензлі різних розмірів;

- маркери, гелева ручка чорного кольору;

- олівці.

\section{Хід творчої роботи}

Перед початком роботи на окремому аркуші паперу потрібно зафіксувати загальні форми майбутнього зображення центрального образу твору, наприклад, ялинки, після чого поступово перейти до винаходу власного погляду на позначення додаткових символічних елементів - необхідних рис святкової атрибутики (іграшек, гірлянд), що допомагає увійти в тематичний напрям представленого творчого завдання, без зайвого наслідування створити власний книжковий знак до виставки студентських робіт «Новорічний екслібрис».

Умовність й, одночасно, чіткість образної фіксації зображення досягається завдяки варіативному пошуку під час етюдного опрацювання вдалого креативного рішення, яке оформлюється виразністю лінійно-контурного позначення головного абрису майбутнього екслібриса. Врешті-решт, з'являється узагальнений образ ялинки, який технічно відтворюється художніми засобами чорно-білої графіки. Таким чином, пошук заповнення художнього простору твору починається 3 чергування висвітленого і затемненого способу нанесення штрихів, що підкреслює технічний бік взаємодії із первинним значенням домінуючої ролі контрастів із самостійним обранням превалюючого рішення: біле на чорному або чорне на білому. 
Також при плануванні композиційних варіантів роботи слід окремо приділити належну увагу текстовому супроводу, адже головною умовою, яка виокремлює екслібрис, є наявність на малюнку відповідного напису латинськими літерами - «EX LIBRIS». Ці слова розкривають призначення цього графічного твору відображати своєрідне входження в історичний світ книжкової культури.

При остаточному затвердженні найбільш вдалого екслібрисного рішення, що відбувається на завершальному етапі обговорення, творчі роздуми студентів належним до «художнього зосереджен- ня» способом необхідно спрямувати на винайдення можливостей комбінації лінійного чи варіативно-асиметричного розміщення текстово-шрифтового супроводу до всієї графічної композиції «Новорічного екслібриса». Як приклад, наведемо роботу Богдана Гончарука, студента II-го курсу спеціальності «Дизайн», яка має назву «Індустріальна ялинка» (див. puс.). Це - книжковий екслібрис в імпровізаційному підході, де за основу береться лінійне відображення уніфікованого урбаністичного змісту, яке композиційно доповнюється лаконічним шрифтовим текстом.

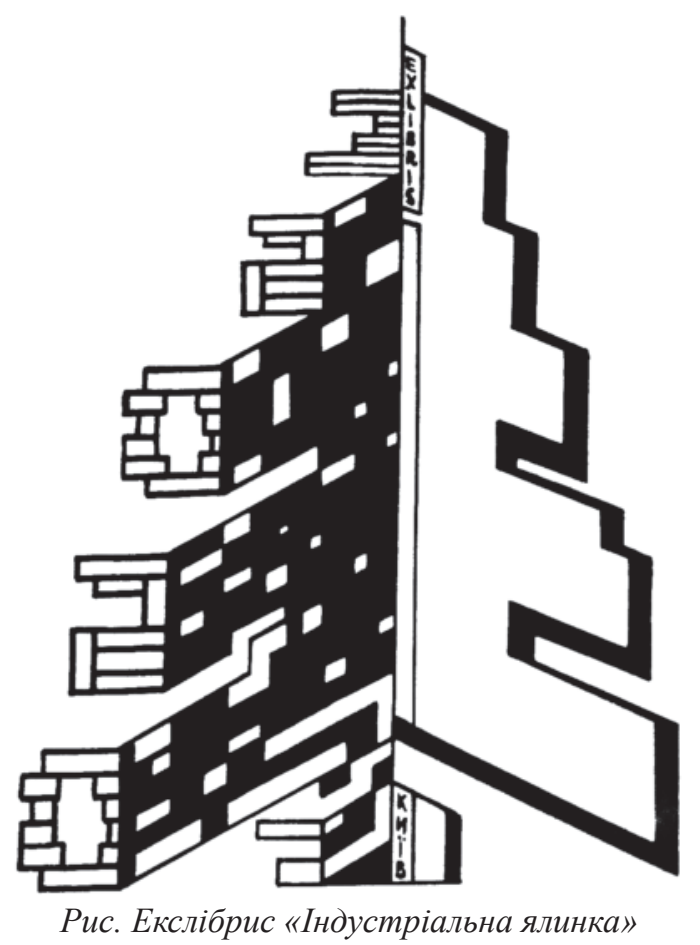

Числовий ряд, ніби сходинками ялинкового гілля, підіймається вгору, де замість святкової гірлянди майорить потрібний «екслібрисний елемент» - латиномовний напис - «EX LIBRIS», відповідно вертикально лінія тексту вдало видовжує композицію «екслібрисної ялинки».

Таким чином, у ході роботи «слід ураховувати i такий аспект, як пошук зв'язку окремих частин i елементів мотиву з підпорядкуванням їх головному композиційному задумові для отримання цілісного гармонійного вирішення» [6, с. 47]. Знову ж таки, варто взяти до уваги деталь, що замість новорічних прикрас ялинка Богдана Гончарука «оформлена» віконними отворами, які схематично запалюють багатоповерхову споруду, що дає змогу уявити щільність міської забудови і відійти від стереотипного уявлення про відношення до розробки новорічної тематики навіть у межах книжково-екслібрисного змісту.

Висновки. Представлена методична розробка доповнюється науковим супроводом відповідного обгрунтування саме того шляху, який дозволяє у цьому дослідженні розкрити можливості підготовки студентів, зокрема і завдяки авторській понятійній експлікації по-особливому важливого естетично-виховного засобу, як «художнє зосередження», до виставково-експозиційної діяльності певного спрямування: оприлюднити креативний потенціал талановитої молоді у межах специфіки додаткового до основної програми завдання - створити власний книжковий знак у тематичній стилістиці «Новорічного екслібриса».

Подальші розвідки у даному напрямі плануємо спрямувати у площину вдосконалення науково-методичної роботи під кутом зору відповідного налаштування студентської молоді до виконання авторських творчих завдань у сфері дизайнерської спеціалізації.

\section{СПИСОК ВИКОРИСТАНОЇ ЛІТЕРАТУРИ}

1. Бердичевський Я. Книжкові знаки сучасників Т. Г. Шевченка. Київ : Дух і Літера, 2007. 84 с.

2. Іванов С. Основи композиції видання. Львів : Світ, 2013. 232 с.

3. Кириченко I. Методичні рекомендації до завдань $з$ офорта для студентів-графіків I курсу НАОМА. Українська академія мистеитва. 2010. Вип. 17. C. $111-122$.

4. Резніченко М. І., Твердохлібова Я. М. Художня графіка. Змістові модулі. Тернопіль : Богдан, 2011. 272 c.

5. Поетика дитячого екслібриса / упоряд., передм. П. В. Нестеренка. Тернопіль : Богдан, 2014. 168 с.

6. Черватюк В. Методичні рекомендації з пленерного живопису для молодих художників. Украӥнська академія мистецтва. 2013. Вип. 21. С. 44-51.

Дата надходження до редакиї: 23.07.2020 р. 